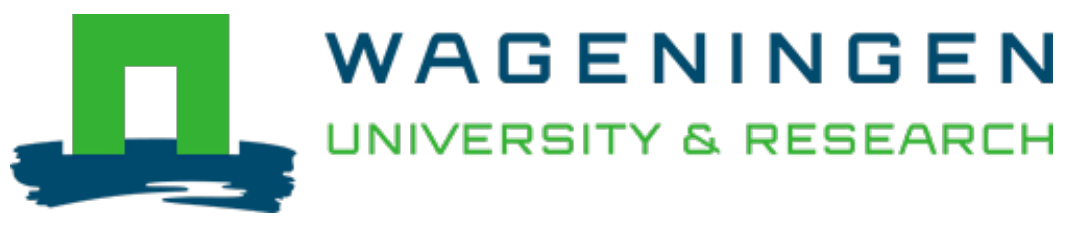

\title{
Changes in soya bean lipids during tempe fermentation.
}

Food Chemistry

Reu, J.C.; Ramdaras, D.; Rombouts, F.M.; Nout, M.J.R.

https://doi.org/10.1016/0308-8146(94)90116-3

This publication is made publicly available in the institutional repository of Wageningen University and Research, under the terms of article $25 \mathrm{fa}$ of the Dutch Copyright Act, also known as the Amendment Taverne. This has been done with explicit consent by the author.

Article $25 \mathrm{fa}$ states that the author of a short scientific work funded either wholly or partially by Dutch public funds is entitled to make that work publicly available for no consideration following a reasonable period of time after the work was first published, provided that clear reference is made to the source of the first publication of the work.

This publication is distributed under The Association of Universities in the Netherlands (VSNU) 'Article $25 \mathrm{fa}$ implementation' project. In this project research outputs of researchers employed by Dutch Universities that comply with the legal requirements of Article $25 \mathrm{fa}$ of the Dutch Copyright Act are distributed online and free of cost or other barriers in institutional repositories. Research outputs are distributed six months after their first online publication in the original published version and with proper attribution to the source of the original publication.

You are permitted to download and use the publication for personal purposes. All rights remain with the author(s) and / or copyright owner(s) of this work. Any use of the publication or parts of it other than authorised under article $25 \mathrm{fa}$ of the Dutch Copyright act is prohibited. Wageningen University \& Research and the author(s) of this publication shall not be held responsible or liable for any damages resulting from your (re)use of this publication.

For questions regarding the public availability of this publication please contact openscience.library@,wur.nl 


\title{
Changes in soya bean lipids during tempe fermentation
}

\author{
J. C. de Reu D. Ramdaras F. M. Rombouts \& M. J. R. Nout* \\ Department of Food Science, Agricultural University, Bomenweg 2, 6703 HD Wageningen, The Netherlands
}

(Received 23 July 1993; accepted 27 September 1993)

\begin{abstract}
Soya beans were fermented with pure cultures of Rhizopus oligosporus and Rhizopus oryzae in perforated petri dishes at $25^{\circ}, 30^{\circ}$ and $37^{\circ} \mathrm{C}$ for $69 \mathrm{~h}$. During fermentation, samples were taken at different time intervals. Lyophilised samples were analysed for total crude lipid (CL), fatty acids present in glycerides (GFA) and free fatty acids (FFA). With $R$. oligosporus, the level of GFA decreased from 22.3 to $11.5 \%\left(\mathrm{w} / \mathrm{w}\right.$, dry matter) after $69 \mathrm{~h}$ fermentation at $37^{\circ} \mathrm{C}$. In the final product, only $4.3 \%$ (w/w, dry matter) of FFA were found, hence the difference of $6.5 \%(\mathrm{w} / \mathrm{w}$, dry matter) of fatty acids were lost. This difference was attributed to assimilation of fatty acids by $R$. oligosporus as a source of carbon. At $25^{\circ} \mathrm{C}$ the situation was different as the level of FFA was 1.7 times higher than could be explained on the basis of the decrease of GFA. The distribution pattern of GFA showed a slight increase of C18:1 and C18:2 during the fermentation at the expense of C18:3. Similar results were obtained with $R$. oryzae. With this fungus the strongest effects were observed at $30^{\circ} \mathrm{C}$ which is close to its optimum temperature for growth. More fatty acids were lost than with $R$. oligosporus and a more pronounced shift in GFA towards saturated fatty acids was observed.
\end{abstract}

\section{INTRODUCTION}

Tempe is a traditional Indonesian food in which filamentous fungi, particularly Rhizopus spp. play an essential role. Yellow-seeded soya beans are the most common and popular raw material. The resulting 'tempe kedele' is usually referred to as 'tempe' (Nout \& Rombouts, 1990). After fermentation, the cake-like mass of soya beans and mould mycelia is sliced and either fried or cooked by other means (Sudarmadji \& Markakis, 1978).

Rhizopus spp. produce a variety of enzymes, including carbohydrases, lipases, proteases and phytases. This paper presents the authors' investigations on the fate of soya bean crude lipid and individual fatty acids during the tempe fermentation. Souser and Miller (1977) reported that lipase activity in tempe fermented with Rhizopus oligosporus was highest after $24 \mathrm{~h}$ of incubation. An enzyme was isolated having a molecular mass of $>100000 \mathrm{Da}$ and optimum $\mathrm{pH} 7$, optimum temperature $40^{\circ} \mathrm{C}$ and which was inactivated after heating at $60^{\circ} \mathrm{C}$ for $10 \mathrm{~min}$. Nahas (1988) reported optimum $\mathrm{pH}$ values for $R$. oligosporus growth and lipase production of 5.5 and 6.5 , respectively. Temperatures ranging from $35-40^{\circ} \mathrm{C}$ favoured the growth of $R$. oligosporus whereas its enzyme production was highest at lower tempera-

* To whom correspondence should be addressed. tures $\left(25^{\circ} \mathrm{C}\right)$. The maximum yield of lipase was obtained at $25^{\circ} \mathrm{C}$ with $\mathrm{pH} 6.5$. In liquid media, maximum $R$. oligosporus lipase activity was obtained after 3 days incubation at $25^{\circ} \mathrm{C}$.

Although various aspects of tempe composition have been studied, the knowledge about changes in lipid and fatty acids composition is incomplete. Wagenknecht et al. (1961) reported an increase of soya bean free fatty acid (FFA) levels fermented by Rhizopus oryzae at $37^{\circ} \mathrm{C}$ : from 0.3 to $8.2 \mathrm{~g} / 100 \mathrm{~g}$ tempe dry matter. Sudarmadji and Markakis (1978) monitored changes of FFA levels in tempe fermented with R.oligosporus at $32^{\circ} \mathrm{C}$ which was subsequently fried in oil. Frying resulted in increased crude lipid (CL) from 8.7 to $26.5 \mathrm{~g} / 100 \mathrm{~g}$ tempe and a decrease of all five FFA present in fresh tempe from 4.45 to $1.72 \mathrm{~g} \mathrm{FFA} / 100 \mathrm{~g}$ tempe dry matter. Hering et al. (1991) compared glyceride-bound fatty acids (GFA) levels in tempe made from various soya bean cultivars with several fungal inocula at different temperatures. They found that the fatty acid composition of tempe is similar to that of soya beans but with higher oleic acid and slightly lower levels of other fatty acids.

The present investigation aims to provide a mass balance of fatty acids occurring in CL, GFA and as FFA in tempe as a function of incubation time and temperature. In addition two strains of the major functional fungi, i.e. $R$. oligosporus and $R$. oryzae are compared. 


\section{MATERIALS AND METHODS}

\section{Organisms}

Rhizopus microsporus var. oligosporus strain LU 575 (NRRL 5905) and Rhizopus oryzae strain LU 583 were grown and maintained at $30^{\circ} \mathrm{C}$ on malt extract agar (CM 59, Oxoid, UK). Sporangiospore suspensions were obtained by scraping off the sporangia from a culture after 7 days incubation at $30^{\circ} \mathrm{C}$, and suspending them in sterile distilled water containing $0 \cdot 1 \%(\mathrm{v} / \mathrm{v})$ Tween 80 (Merck, Germany). The viable count varied between $5 \times 10^{5}$ and $10^{6} \mathrm{cfu} / \mathrm{ml}$, when determined on RoseBengal Chloramphenicol Agar (CM 549, Oxoid, UK). The sporangiospore suspensions were used immediately after preparation.

\section{Tempe manufacturing process}

Dehulled yellow-seeded soya beans (Glycine max) were soaked overnight using the accelerated acidification method ( $\mathrm{pH}$ of the soak water $<4.2$ ) (Nout et al., 1987). Subsequently, the beans were washed with tap water and boiled for $20 \mathrm{~min}$, cooled, superficially dried (15-30 min, at room temperature) and inoculated using a sporangiospore suspension $(1 \% \mathrm{v} / \mathrm{w})$. Petri dishes (dia. $9 \mathrm{~cm} ; 5$ perforations/side, dia. $1 \mathrm{~mm}$ ) were filled with $60 \mathrm{~g}$ inoculated beans, sealed with tape and incubated at 25,30 or $37^{\circ} \mathrm{C}$. Samples were taken at various time intervals and were analysed for moisture content. Remaining sample was frozen at $-20^{\circ} \mathrm{C}$, lyophilised and stored under vacuum at $4^{\circ} \mathrm{C}$ in the dark until analysis. Although incubation is stopped after $30-48 \mathrm{~h}$ under production conditions, the fermentation was continued for up to $70 \mathrm{~h}$ to observe the effects of on-going biochemical processes.

\section{Chemical analyses}

The lyophilized tempe samples were ground with a mill (Type 32002, Moulinex, France) to a fine powder, and $7.0 \mathrm{~g}$ samples were extracted with petroleum-ether (40:60) in Soxhlet extractors. The ether was evaporated, and quantification of the total CL content was carried out gravimetrically. FFA and GFA were determined by gas-liquid chromatography (GC) of their respective methyl esters according to Metcalfe and Wang (1981), using a methyl ester of heptadecanoic acid (C17:0, margaric acid) (Merck, Darmstadt, Germany) as an internal standard. A Perkin Elmer chromatograph (Sigma 3B, Norwalk, CT, USA) with a flame ionisation detector and an HP3380A integrator (Hewlett Packard, Geneva, Switzerland) was used. Chromatographic conditions were as follows: column, length $2 \mathrm{~m}$, internal diameter $2 \mathrm{~mm}$, external diameter $1 / 8$ inch (Chrompack, Bergen op Zoom, The Netherlands); stationairy phase, $15 \%$ CP-Sil 84 on CHROM WHP, 100-200 mesh; injection temperature, $225^{\circ} \mathrm{C}$; detector temperature, $250^{\circ} \mathrm{C}$; column temperature, $180^{\circ} \mathrm{C}$; carrier gas, $\mathrm{N}_{2}$.

\section{RESULTS}

\section{Total crude lipid content (CL)}

Changes of the total CL content are shown in Figs 1(a) and 1(b). The data presented for CL are means of duplicate measurements. For each data point the coefficient of variation $(\mathrm{CV})$ was $<4.6 \%$. With $R$. oligosporus (Fig. 1(a)), CL diminished after the period of most active growth (after $40 \mathrm{~h}$ at $25^{\circ} \mathrm{C}, 24 \mathrm{~h}$ at $30^{\circ} \mathrm{C}$ or $16 \mathrm{~h}$ at $37^{\circ} \mathrm{C}$ ). This was more pronounced at higher incubation temperatures and reached $30 \%$ of the initial value after $69 \mathrm{~h}$ of fermentation at $37^{\circ} \mathrm{C}$. $R$. oryzae (Fig. 1(b)) gave a slight increase of $\mathrm{CL}$ during most active growth $(20-30 \mathrm{~h})$ at all temperatures, which was also followed by a decline. However, with $R$. oryzae the strongest decrease of $\mathrm{CL}$ took place at $30^{\circ} \mathrm{C}$ with $21 \%$ of the initial value and was thus less pronounced than with $R$. oligosporus.

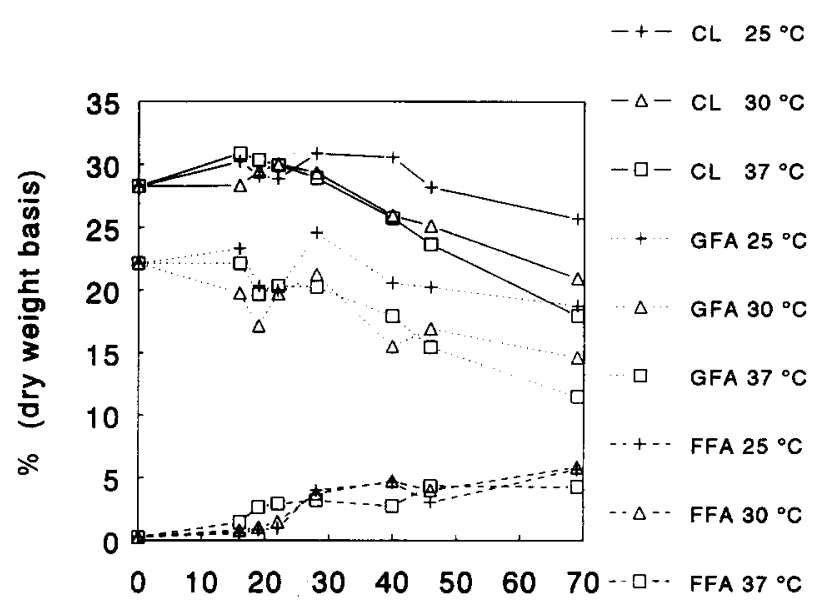

Fermentation period (h)

(a)

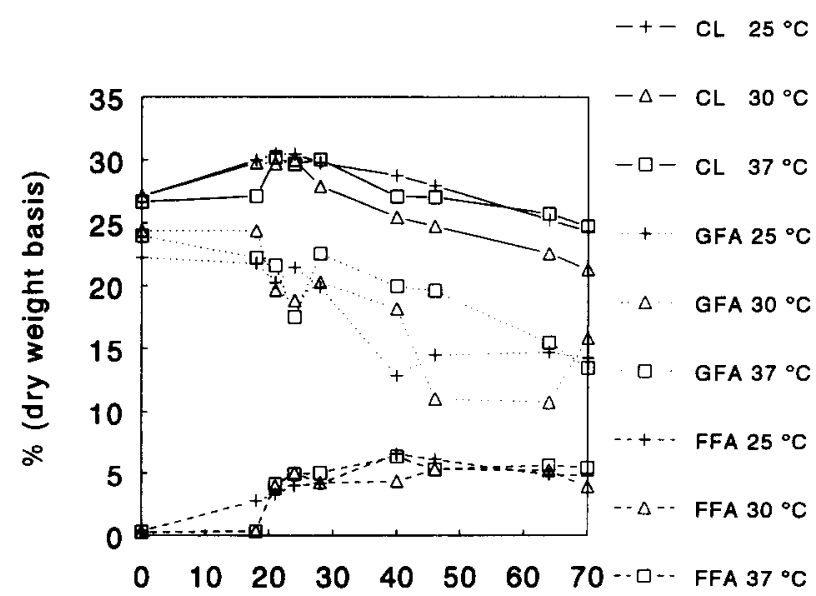

Fermentation period (h)

(b)

Fig. 1. Changes of total crude lipid (CL), glyceride fatty acids (GFA) and free fatty acids (FFA) during fermentation of soya beans in perforated petri dishes at 25,30 and $37^{\circ} \mathrm{C}$, with (a)Rhizopus oligosporus, and (b)Rhizopus oryzae. 
Table 1. Levels of glyceride fatty acids (GFA) and free fatty acids (FFA) during soya bean fermentation at $30^{\circ} \mathrm{C}$

\begin{tabular}{|c|c|c|c|c|c|c|c|c|c|c|c|c|c|}
\hline \multirow{2}{*}{$\begin{array}{l}\text { Incubation time } \\
\text { (h) }\end{array}$} & \multicolumn{2}{|c|}{$\mathrm{C16:0}$} & \multicolumn{2}{|c|}{ C18:0 } & \multicolumn{2}{|c|}{ C18:1 } & \multicolumn{2}{|c|}{ C18:2 } & \multicolumn{2}{|c|}{$\mathrm{C} 18: 3$} & \multicolumn{3}{|c|}{ TOTAL } \\
\hline & $\mathrm{GFA}^{a}$ & $\mathrm{FFA}^{b}$ & GFA & FFA & GFA & FFA & GFA & FFA & GFA & FFA & GFA & FFA & $\mathrm{FA}^{c}$ \\
\hline \multicolumn{14}{|c|}{ Rhizopus oligosporus } \\
\hline 0 & $2 \cdot 5$ & $0 \cdot 1$ & 0.7 & 0.0 & $5 \cdot 1$ & $0 \cdot 1$ & $12 \cdot 3$ & 0.0 & 1.6 & 0.0 & $22 \cdot 2$ & $0 \cdot 3$ & 22.4 \\
\hline 16 & $2 \cdot 2$ & 0.1 & 0.6 & 0.0 & $4 \cdot 5$ & $0 \cdot 1$ & 11.0 & 0.6 & 1.4 & 0.0 & $19 \cdot 8$ & 0.8 & $20 \cdot 6$ \\
\hline 19 & 1.9 & 0.2 & 0.6 & 0.0 & 3.9 & $0 \cdot 1$ & $9 \cdot 6$ & 0.8 & 1.2 & 0.0 & 17.2 & 1.0 & $18 \cdot 2$ \\
\hline 22 & $2 \cdot 1$ & $0 \cdot 3$ & 0.6 & 0.0 & $4 \cdot 3$ & 0.2 & $11 \cdot 2$ & 1.0 & 1.4 & 0.0 & $19 \cdot 7$ & 1.5 & $21 \cdot 2$ \\
\hline 28 & $2 \cdot 3$ & 0.7 & 0.6 & 0.2 & 5.9 & 0.7 & $12 \cdot 1$ & $2 \cdot 0$ & 1.4 & $0 \cdot 2$ & $21 \cdot 3$ & $3 \cdot 8$ & $25 \cdot 0$ \\
\hline 40 & 1.6 & 0.8 & 0.5 & 0.2 & $3 \cdot 8$ & $1 \cdot 0$ & 8.8 & $2 \cdot 4$ & 0.9 & $0 \cdot 2$ & $15 \cdot 5$ & $4 \cdot 8$ & $20 \cdot 3$ \\
\hline 46 & 1.7 & 0.7 & 0.5 & $0 \cdot 2$ & $4 \cdot 2$ & 0.9 & $9 \cdot 6$ & $2 \cdot 1$ & 0.9 & $0 \cdot 2$ & $16 \cdot 9$ & $4 \cdot 0$ & $21 \cdot 0$ \\
\hline 69 & 1.4 & 0.9 & 0.4 & $0 \cdot 3$ & 3.7 & 1.4 & $8 \cdot 3$ & $3 \cdot 0$ & 0.9 & $0 \cdot 3$ & $14 \cdot 7$ & 5.9 & $20 \cdot 5$ \\
\hline \multicolumn{14}{|l|}{ Rhizopus oryzae } \\
\hline 0 & $2 \cdot 7$ & $0 \cdot 1$ & 0.8 & 0.0 & $5 \cdot 4$ & $0 \cdot 1$ & 13.9 & 0.0 & 1.8 & 0.0 & $24 \cdot 4$ & $0 \cdot 3$ & $24 \cdot 7$ \\
\hline 18 & $2 \cdot 6$ & $0 \cdot 1$ & 0.8 & 0.0 & $5 \cdot 5$ & $0 \cdot 1$ & $13 \cdot 7$ & $0 \cdot 1$ & 1.8 & 0.0 & $24 \cdot 4$ & 0.4 & $24 \cdot 8$ \\
\hline 21 & 1.9 & 0.9 & 0.6 & 0.2 & $4 \cdot 5$ & $0 \cdot 8$ & $11 \cdot 3$ & 1.9 & $1 \cdot 3$ & $0 \cdot 2$ & $19 \cdot 6$ & $4 \cdot 0$ & 23.6 \\
\hline 24 & 1.9 & $1 \cdot 1$ & 0.5 & $0 \cdot 3$ & $4 \cdot 3$ & 0.9 & $10 \cdot 9$ & $2 \cdot 4$ & $1 \cdot 3$ & $0 \cdot 3$ & $18 \cdot 8$ & $5 \cdot 1$ & 23.9 \\
\hline 28 & 1.9 & 1.0 & 0.5 & $0 \cdot 3$ & $4 \cdot 7$ & $0 \cdot 8$ & $11 \cdot 8$ & $2 \cdot 0$ & 1.4 & $0 \cdot 2$ & $20 \cdot 3$ & $4 \cdot 4$ & $24 \cdot 7$ \\
\hline 40 & 1.6 & 1.0 & 0.5 & $0 \cdot 3$ & $4 \cdot 2$ & 0.9 & $10 \cdot 6$ & $2 \cdot 0$ & $1 \cdot 2$ & $0 \cdot 2$ & $18 \cdot 2$ & $4 \cdot 4$ & $22 \cdot 5$ \\
\hline 46 & $1 \cdot 1$ & 1.0 & $0 \cdot 3$ & $0 \cdot 3$ & $2 \cdot 6$ & $1 \cdot 3$ & $6 \cdot 4$ & $2 \cdot 5$ & $0 \cdot 6$ & $0 \cdot 2$ & 11.0 & $5 \cdot 3$ & $16 \cdot 3$ \\
\hline 64 & $1 \cdot 1$ & 0.9 & $0 \cdot 3$ & $0 \cdot 3$ & $2 \cdot 6$ & 1.4 & $6 \cdot 2$ & $2 \cdot 5$ & 0.6 & $0 \cdot 2$ & $10 \cdot 7$ & $5 \cdot 2$ & $16 \cdot 0$ \\
\hline 70 & 1.7 & 0.6 & 0.4 & $0 \cdot 2$ & 3.7 & $1 \cdot 1$ & $9 \cdot 1$ & $2 \cdot 0$ & 0.9 & $0 \cdot 1$ & $15 \cdot 8$ & 4.0 & 19.8 \\
\hline
\end{tabular}

${ }^{a, b}$ Expressed as \% of dry matter.

${ }^{c}$ FA, fatty acid.

\section{GFA versus FFA}

Total GFA and total FFA are shown in Figs 1(a) and 1(b). The data points for GFA and FFA were based on single results, after it had been verified that the $\mathrm{CV}$ of the GC analyses was $<1.9 \%$. In Figure $1(a)$ it is shown that $R$. oligosporus reduced the GFA with $15 \cdot 4,35.4$ or $48 \%$ after $69 \mathrm{~h}$ of fermentation at 25,30 or $37^{\circ} \mathrm{C}$, respectively. During the same period the FFA increased by $5.7,5.9$ or $4.3 \%$ of dry matter at 25,30 or $37^{\circ} \mathrm{C}$, respectively. When the GFA decreases were compared with FFA increases, an overall loss of fatty acids of $54 \%$ of the initial level at $37^{\circ} \mathrm{C}$ was observed. At $30^{\circ} \mathrm{C}$, an overall loss of $21 \%$ took place, whereas at $25^{\circ} \mathrm{C}$ there was an apparent increase of fatty acids of $70 \%$ compared to the initial level. With $R$. oryzae a GFA decrease of $7.9,8.6$ and $10.2 \%$ of the dry matter at 25 , 30 and $37^{\circ} \mathrm{C}$, respectively, was found. During this period the FFA levels increased with $4.8,3.9$ and $5.5 \%$ at 25,30 and $37^{\circ} \mathrm{C}$, respectively. Here again, losses of 39,54 and $46 \%$ of the initial level of fatty acids occurred at 25,30 and $37^{\circ} \mathrm{C}$, respectively.

\section{GFA patterns}

In dehulled soya beans, the following distribution of GFA was found after soaking and cooking: palmitic acid C16:0 (11.2\% of total GFA), stearic acid C18:0 (3.3\%), oleic acid C18:1 (23.0\%), linoleic acid C18:2 $(55 \cdot 6 \%)$ and linolenic acid C18:3 (7.0\%). In Figure 1(a), total GFA decreased with time and with increasing incubation temperature for $R$. oligosporus. In Table 1, the individual levels of GFA during fermentation at $30^{\circ} \mathrm{C}$ are presented. These follow a similar trend as that of total GFA shown in Fig. 1(a). There was a slight decrease until $19 \mathrm{~h}$ followed by a slight increase during the period of most active growth. Beyond $28 \mathrm{~h}$ of fermentation, the levels of all GFA decreased. Compared with the initial levels of individual GFA (at time $=0)$, the minority fatty acids (C16:0, C18:0 and $\mathrm{C} 18: 3)$ decreased faster than the majority fatty acids (C18:1 and $\mathrm{C} 18: 2$ ). With $R$. oryzae at $30^{\circ} \mathrm{C}$, GFA decreased until $64 \mathrm{~h}$ and slightly increased again. As can be seen in Fig. 1(b), this did not occur at 25 or $37^{\circ} \mathrm{C}$. The distribution of the individual GFA was similar as with $R$. oligosporus. The effect of temperature on the GFA pattern is shown in Figs 2(a) and 2(b). With both Rhizopus spp. the distribution of GFA developed in a similar pattern at all temperatures, i.e. C18:3 tended to decrease more than the other fatty acids. With $R$. oligosporus this was most pronounced at $37^{\circ} \mathrm{C}$ and with $R$. oryzae at $30^{\circ} \mathrm{C}$.

\section{FFA patterns}

As was shown in Figs 1(a) and 1(b), the levels of FFA increased during fermentation. With $R$. oligosporus at $25^{\circ} \mathrm{C}$, more FFA was retrieved than expected on the basis of GFA decrease. At 30 and $37^{\circ} \mathrm{C}$ considerably less FFA was found than expected. Figures 3(a) and 3(b) show the level and distribution pattern of individual FFA expressed as a percentage of the expected level. The expected level of FFA equals the decrease of GFA between time $=0$ and $46 \mathrm{~h}$ of fermentation. With $R$. oligosporus at $25^{\circ} \mathrm{C}$ (Fig. 3(a)), about twice as much $C 18: 1$ and $C 18: 2$ but less $C 18: 3$ were found than expected on the basis of GFA decrease. At the higher temperatures, the pattern of FFA shifted towards a higher degree of saturation, but FFA levels were generally lower. With $R$. oryzae (Fig 1(b)), total FFA levels 


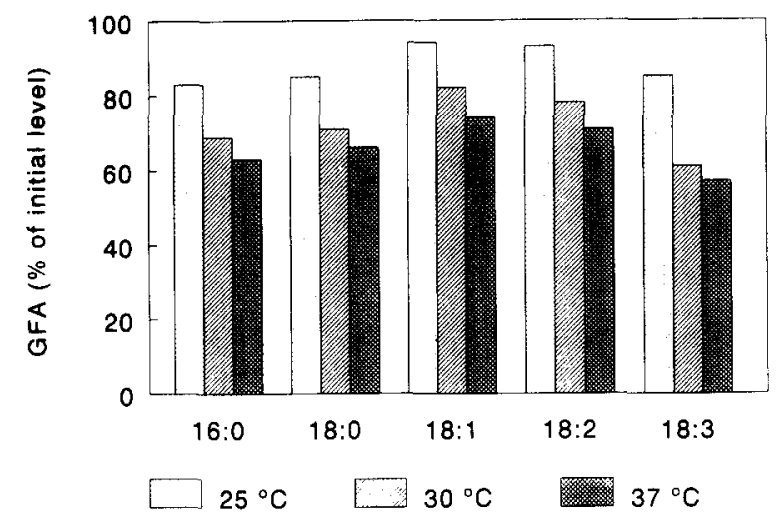

(a)

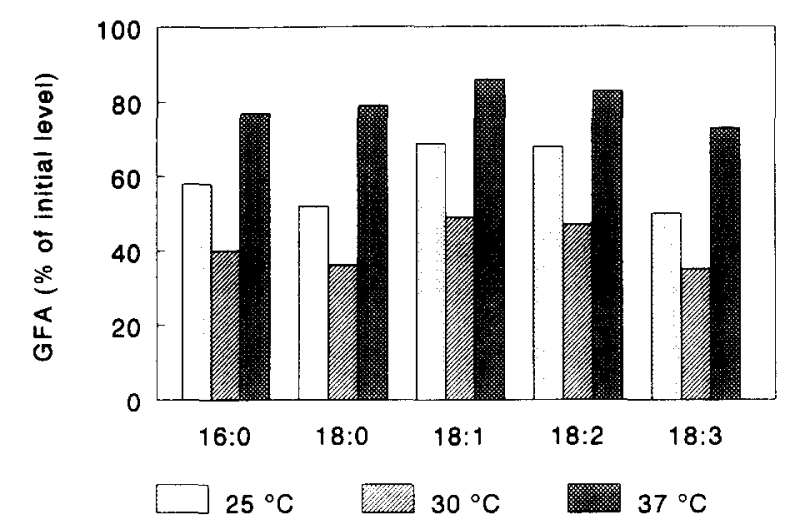

(b)

Fig. 2. Relative changes of GFA distribution after $46 \mathrm{~h}$ of fermentation of soya beans in perforated petri dishes at 25,30 and $37^{\circ} \mathrm{C}$, with (a)Rhizopus oligosporus and (b)Rhizopus oryzae.

were lower than expected from the GFA decrease. However, for the individual FFAs there were some remarkable differences between the respective incubation temperatures. At $25^{\circ} \mathrm{C}$, there was an increase in $\mathrm{C16:0}$ and $\mathrm{C} 18: 0$. At $37^{\circ} \mathrm{C}, \mathrm{C} 18: 1$ and $\mathrm{C} 18: 2$ exceeded $100 \%$, and at $30^{\circ} \mathrm{C}$ the residual FFAs showed a general tendency towards a higher degree of saturation.

\section{DISCUSSION}

During the tempe fermentation, a temperature-related decrease of total CL content was observed. With $R$. oligosporus, strongest CL reduction was $39 \%$ of the initial level after $69 \mathrm{~h}$ of fermentation at $37^{\circ} \mathrm{C}$. $R$. oligosporus has an optimum growth temperature between 35 and $37^{\circ} \mathrm{C}$. $R$. oryzae has its optimum growth temperature at approximately $30^{\circ} \mathrm{C}$. In the experiment with $R$. oryzae at 25 and $37^{\circ} \mathrm{C}$ we obtained a less pronounced decrease of $\mathrm{CL}$ than at $30^{\circ} \mathrm{C}$. The data presented here suggest that the decrease of $\mathrm{CL}$ is related to the growth rate.

Earlier investigations of $\mathrm{CL}$ changes during tempe fermentation did not include the effect of incubation temperature or microbial strain. Van Buren et al. (1972) reported a CL decrease of $18 \%$ after $72 \mathrm{~h}$ of

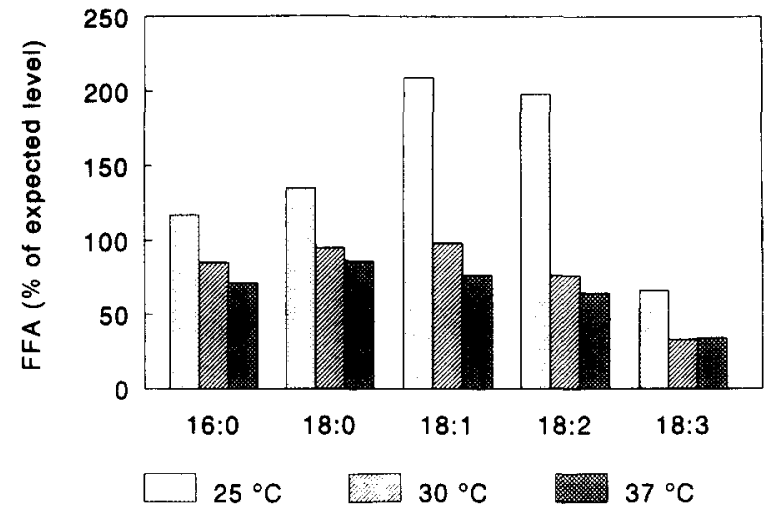

(a)

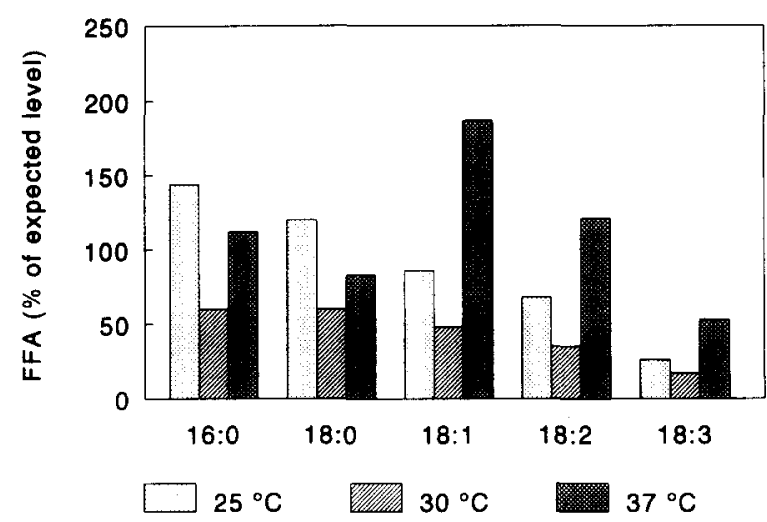

(b)

Fig. 3. Changes of FFA distribution after $46 \mathrm{~h}$ of fermentation of soya beans in perforated petri dishes at 25,30 and $37^{\circ} \mathrm{C}$, with (a)Rhizopus oligosporus and (b)Rhizopus oryzae. The expected FFA level corresponds with the quantity of GFA which disappeared during $46 \mathrm{~h}$ of fermentation at 25 , 30 or $37^{\circ} \mathrm{C}$, respectively.

fermentation at $38^{\circ} \mathrm{C}$ using a mixed culture of Rhizopus spp. Van Veen and Schaefer (1950) found a CL decrease of $30 \%$ with $R$. oryzae at $30^{\circ} \mathrm{C}$. Wagenknecht et al. (1961) reported that tempe fermented at $37^{\circ} \mathrm{C}$ with $R$. oryzae had a fairly constant CL level varying from 22.3 to $26.7 \%$. Hering et al. (1991) reported that a significant CL loss could not be detected with different Rhizopus spp. at 24,32 and $36^{\circ} \mathrm{C}$. The difference between the present results and those obtained by Hering et al. (1991) are probably caused by the different methods of acidification. During the accelerated acidification method (Nout et al., 1987) profuse growth of lactic acid bacteria occurs. By consequence, a decrease of fermentable carbohydrates takes place. This can cause a quicker depletion of assimilable carbohydrates and, hence, a shift towards the use of lipids as a source of energy and carbon during the stage of fungal fermentation. With the chemical acidification procedure used by Hering et al. (1991), the fermentable sugars remain available for the fungal fermentation stage. Consequently, less $\mathrm{CL}$ will be assimilated during the fermentation.

With $R$. oligosporus grown at $25^{\circ} \mathrm{C}$, the apparent increase of CL during the period of most active growth is 
due to active assimilation of carbohydrates and limited consumption of lipids, causing a shift in the dry matter composition resembling an enrichment of CL.

The results for $R$. oligosporus show that at $30^{\circ} \mathrm{C}$ and $37^{\circ} \mathrm{C}$, the GFA decrease is larger than the FFA increase. This difference is created after the period of most active mould growth $(20-30 \mathrm{~h})$. The disappearance of the liberated FFA indicates that the fungus metabolised the latter as a carbon source. Indeed, $R$. oligosporus was shown to grow on soya oil as a carbon source (Nahas, 1988). The fact that fatty acids disappear after the most active growth period implies that fatty acids are not the preferred carbon source.

Although tempe production usually takes place under uncontrolled conditions, the results presented indicate that it will be possible to influence the fatty acid pattern by varying the incubation temperature. In order to ensure maximum nutritional value of the product, it will be of interest to optimise bean pretreatments, incubation temperatures and periods in order to avoid undesirable losses of fatty acids.

\section{ACKNOWLEDGEMENTS}

The authors gratefully acknowledge the financial support of Nutricia Research, Zoetermeer, The Netherlands.

\section{REFERENCES}

Hering, L., Bisping, B. \& Rehm, H.J. (1991). Patterns and formation of fatty acids at tempe fermentation by several strains of Rhizopus sp. Fat Sci. Technol., 93, 303-8.

Metcalfe, L.D. \& Wang, C.N. (1981). Rapid preparation of fatty acid methyl esters using organic base-catalysed transesterification. J. Chrom. Sci., 19, 530-5.

Nahas, E. (1988). Control of lipase production by Rhizopus oligosporus under various growth conditions. J. Gen. Microbiol., 134: 227-33.

Nout, M.J.R. \& Rombouts, F.M. (1990). Recent developments in tempe research J. Appl. Bacteriol., 69, 609-33.

Nout, M.J.R., De Dreu, M.A., Zuurbier, A.M. \& Bonantsvan Laarhoven, T.M.G. (1987). Ecology of controlled soya bean acidification for tempe manufacture. Food Microbiol., 4, 165-72.

Souser, M.L. \& Miller, L. (1977). Characterization of the lipase produced by Rhizopus oligosporus, the tempeh fungus. Abstr. Ann. Meeting Am. Soc. Microbiol, , 77, 258.

Sudarmadji, S. \& Markakis, P. (1978). Lipid and other changes during the fermentation and frying of tempeh. Food Chem., 3, 165-70.

Van Buren, J.P., Hackler, L.R. \& Steinkraus, L.H. (1972). Solubilization of Soybean Tempeh Constituents during fermentation. Cereal Chem., 49, 208-11.

Van Veen, A.G. \& Schaefer, G. (1950). The influence of the tempeh fungus on the soya bean. Doc. Neerl. et Indones. Morb. Trop., 2, 270-81.

Wagenknecht, A.C., Mattick, L.R., Lewin, L.M., Hand, D.B. \& Steinkraus, K.H. (1961). Changes in soybeans lipids during tempeh fermentation. $J$. Food Sci., 26, 373-78. 